\title{
Epidemiological Study of Thoracolumbar Pott's Spine at a Tertiary Care Hospital in North India
}

\author{
Asheesh Kumar Gupta, Aditya Srivastava, R.L.S. Sengar \\ Department of Neurosurgery G.R. Medical College Gwalior, INDIA
}

\begin{abstract}
The vertebral column is involved in less than $1 \%$ of all the cases of tuberculosis. It can associated with major neurological deficits due to compression of adjacent neural structures with significant deformity of spinal column. Therefore, early diagnosis and management of spinal TB has special importance in preventing these serious complications. In order to extract current trends in diagnosis and medical or surgical treatment of spinal TB we performed a review with patients admitted to our hospital between 2016 and 2017. Although the development of more accurate imaging modalities such as magnetic resonance imaging and advanced surgical techniques have made the early diagnosis and management of spinal TB much easier, these are still very challenging topics. In this review we aim to discuss the diagnosis and management of spinal TB based on studies with acceptable design, clearly explained results and justifiable conclusions.
\end{abstract}

Key words: Cobb's angle, Pott's spine

\section{Introduction}

Tuberculosis is a very common disease in developing countries affecting a large proportion of population. It is a major cause of mortality and morbidity in India. There are large number of cases having extrapulmonary tuberculosis. Vertebral column is a common site for extra-pulmonary tuberculosis. The entity is called as Pott's spine. Pott's disease, described by Sir Percival Pott, is one of the oldest demonstrated diseases affecting humans [1,2]. The thoracolumbar spine is the most commonly affected, with less frequent involvement of the cervical and sacral spine [3]. Tuberculous spondylitis is diagnosed in the second, third, or fourth decade of life in developing nations, with a male to female ratio ranging from 1.3 : 1 to $1.7: 1[2,3,4-6]$. Neurologic deficits with or without kyphotic deformities are a frequent sequelae of serious disease [7].

\section{Material and methods}

The study was conducted in the Department of Neurosurgery, G. R. Medical College and Jay Arogya Hospital, Gwalior, 
M.P. India, over a period of one years. Of all patients with thoracolumbar Pott's spine admitted in the hospital during the study period were included. Patients of all age groups and both sexes were included in the study. These cases were analyzed for age, sex incidence, location and histopathological diagnosis. Statistical analysis was done by calculating the numbers and percentage for computing the incidence in various age groups, in sexes, location.

Study design: A meta analysis

Ethical approval: The study was undertaken after consent and clearance by the ethical committee of G.R. Medical College Gwalior.

Inclusion criteria: Of all patients admitted with thoracolumbar Pott's spine during the period 2016 - 2017 were included.

Exclusion criteria: Patients with Cervical Pott's were excluded.

Sample size: Fifty patients

Methodology: Age, Sex, Location, presenting complaints were studied.

Statistical analysis: It was done by calculating number and percentage for computing the incidence in various age groups, in sexes, location and also comparison with other studies.

\section{Observation}

The present study comprises of 50 patients of thoracolumbar Pott's spine admitted in the department of Neurosurgery, G.R. Medical college Gwalior \& J.A. Group of Hospitals, Gwalior from Feb 2016 to Aug 2017.
Table 1

Age Wise distribution of patients

\begin{tabular}{|l|r|r|}
\hline \multicolumn{1}{|c|}{ Age in Years } & No of patients & \multicolumn{1}{c|}{ Percentage } \\
\hline up to 10 & 4 & $8 \%$ \\
\hline $11-20$ & 4 & $8 \%$ \\
\hline $21-40$ & 20 & $40 \%$ \\
$41-60$ & 17 & $34 \%$ \\
\hline$>60$ & 5 & $10 \%$ \\
\hline
\end{tabular}

The mean age of patients in the study was 38.24 years.

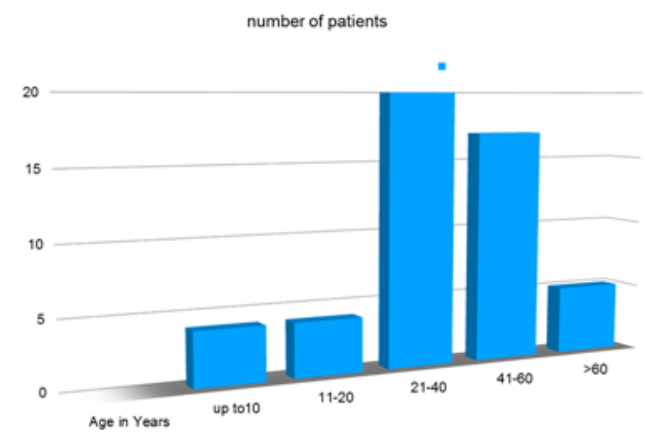

Table 2

Sex wise distribution of patients

\begin{tabular}{|l|r|r|}
\multicolumn{1}{|c|}{ Sex } & Number of patients & \multicolumn{1}{c|}{ Percentage } \\
\hline male & 25 & $50 \%$ \\
\hline Female & 25 & $50 \%$ \\
\hline
\end{tabular}

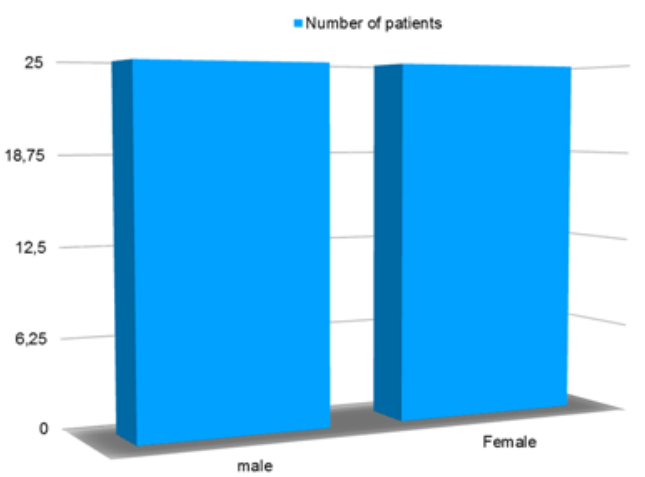


Table 3

Distribution according to location of disease

\begin{tabular}{|l|r|r|}
\hline Location of disease & \multicolumn{1}{|c|}{$\begin{array}{c}\text { Number of } \\
\text { patients }\end{array}$} & Percentage \\
\hline $\begin{array}{l}\text { Upper Dorsal spine } \\
\text { D1-4 }\end{array}$ & 7 & $14 \%$ \\
\hline $\begin{array}{l}\text { Mid Dorsal spine } \\
\text { D4-8 }\end{array}$ & 11 & $22 \%$ \\
\hline $\begin{array}{l}\text { Lower Dorsal spine } \\
\text { D8-12 }\end{array}$ & 23 & $46 \%$ \\
Lumbar spine L1-5 & 9 & $18 \%$ \\
\hline
\end{tabular}

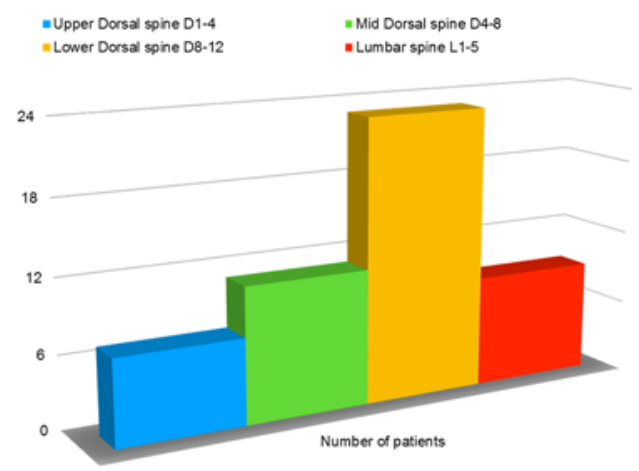

In the present study we have found that dorsal spine was most commonly affected (72\%) while lumbar spine was affected in only $18 \%$ of the cases.

Table 4

Clinical features

\begin{tabular}{|l|r|r|}
\hline Sign and symptoms & $\begin{array}{l}\text { Number of } \\
\text { patients }\end{array}$ & Percentage \\
\hline $\begin{array}{l}\text { Backache } \\
\begin{array}{l}\text { Motor weakness in lower } \\
\text { limb (paraparesis) }\end{array}\end{array} \quad 45$ & $100 \%$ \\
\hline Paraplegia & $50 \%$ \\
\hline
\end{tabular}

\begin{tabular}{|l|r|r|}
\hline Sign and symptoms & $\begin{array}{l}\text { Number of } \\
\text { patients }\end{array}$ & Percentage \\
\hline Sensory Deficits & 43 & $86 \%$ \\
\hline $\begin{array}{l}\text { Autonomic disturbances } \\
\text { (Bowel and bladder } \\
\text { involvement) }\end{array}$ & 18 & $36 \%$ \\
\hline immobility & 44 & $88 \%$ \\
\hline
\end{tabular}
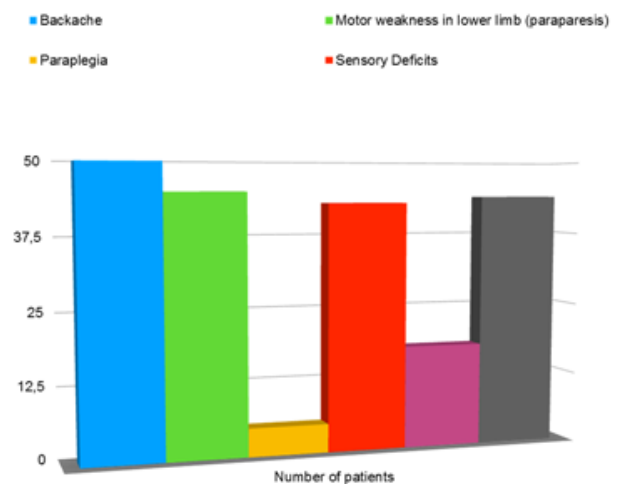

In the present study back pain is the most common presenting symptom and found in all the patients taken in the study while motor weakness in form of paraparesis or paraplegia was the second most common symptom noted.

\section{Discussion}

It is estimated that almost six billion people are infected with $\mathrm{TB}$ and over nine million new cases of active TB occur annually with two to three million deaths. Extra pulmonary TB accounts for about $15-20 \%$ of all cases and nearly $1-3 \%$ of patients suffering from TB have involvement of the skeletal system.

The present study has been carried out in the department of neurosurgery, G.R. Medical college, Gwalior on the patients of 
the thoracolumbar Pott's spine during February 2016 to August 2017. Total 50 cases of thoracolumbar Pott's spine were studied .

In present study patients have found that thoracolumbar Pott's spine presented in age group ranging from 4 years to 68 years, with mean age of 38.24 years.

In present study we have found that there were $25(50 \%)$ male and $25(50 \%)$ female patients.

On comparison with various studies we found a near similar age and sex incidence.

Table 5

Age and sex wise distribution of the patients

\begin{tabular}{|c|c|c|c|c|}
\hline s.n & Study & $\begin{array}{c}\text { Age } \\
\text { group } \\
\text { (years) }\end{array}$ & $\begin{array}{c}\text { Mean } \\
\text { age } \\
\text { (years) }\end{array}$ & $\begin{array}{c}\text { Sex ratio } \\
\text { (M:F) }\end{array}$ \\
\hline 1 & Present Study & $4-68$ & 38.24 & $50: 50$ \\
\hline 2 & $\begin{array}{l}\text { M. Ehasei et al. } \\
(8)\end{array}$ & $5-80$ & 42.5 & $48: 52$ \\
\hline 3 & Park et al. (9) & $10-76$ & 44 & $50: 50$ \\
\hline 4 & Kenyon et al. (10) & $14-65$ & 29 & $47: 53$ \\
\hline 5 & Su et al. (11) & $10-88$ & 44.5 & $50: 50$ \\
\hline 6 & Barriere et al. (12) & $20-76$ & 42 & $56: 44$ \\
\hline & $\begin{array}{l}\text { Alothman et al. } \\
\text { (13) }\end{array}$ & $15-80$ & 53 & $53: 47$ \\
\hline & $\begin{array}{l}\text { Solagberu et al. } \\
(14)\end{array}$ & $2-70$ & 27 & 48:52 \\
\hline
\end{tabular}

\section{Location wise distribution}

In this study, out of fifty patients with Pott's disease of the spine, thoracic spine was the most affected levels of the spine; where in 34 patients $(68 \%)$ was found to be affected with tuberculosis. In 7 cases (14\%) the disease affected the thoracolumbar vertebrae (D12-L1) and in 9 cases (18\%) it was in the lumbar spines.
Table 6

Location wise distribution

\begin{tabular}{|c|c|c|c|c|}
\hline S.N. & Study & $\begin{array}{c}\text { thoracic } \\
(\%)\end{array}$ & $\begin{array}{c}\text { Thoraco } \\
\text { lumbar (\%) }\end{array}$ & $\begin{array}{c}\text { Lumbar } \\
(\%)\end{array}$ \\
\hline 1 & Present study & 68 & 14 & 18 \\
\hline 2 & $\begin{array}{l}\text { M. Ehsaei et al. } \\
(8)\end{array}$ & 46 & 10 & 33 \\
\hline 3 & Park et al. (9) & 78 & 11 & 20 \\
\hline 4 & $\begin{array}{l}\text { Kenyon et al. } \\
(10)\end{array}$ & 65 & - & 41 \\
\hline 5 & Su et al. (11) & 33 & 17 & 42 \\
\hline 6 & $\begin{array}{l}\text { Barriere et al. } \\
(12)\end{array}$ & 48 & 0 & 21 \\
\hline 7 & $\begin{array}{l}\text { Alothman et al. } \\
\text { (13) }\end{array}$ & 55 & - & 36 \\
\hline 8 & $\begin{array}{l}\text { Solagberu et al. } \\
(14)\end{array}$ & 24 & 24 & 44 \\
\hline
\end{tabular}

\section{Clinical features}

Among the 50 patients studied the most common symptom was back pain $50(100 \%)$, fever detected in 12(24\%), malaise in 9(18\%) and weight loss in 25(50\%) of cases. In neurologic examination $45(90 \%)$ had paraparesis. $43(86 \%)$ had sensory loss, $18(36 \%)$ of patients complained of sphincter problem, and immobility $44(88 \%)$ cases.

\section{Table 7}

Clinical features

\begin{tabular}{|r|c|c|c|c|c|}
\hline S.N. & Study & $\begin{array}{r}\text { Back } \\
\text { pain }\end{array}$ & $\begin{array}{c}\text { Parapares } \\
\text { is }\end{array}$ & $\begin{array}{c}\text { sensory } \\
\text { loss }\end{array}$ & $\begin{array}{c}\text { Autonomic } \\
\text { disturbance } \\
\text { s }\end{array}$ \\
\hline 1 & $\begin{array}{l}\text { Present } \\
\text { study }\end{array}$ & 100 & 90 & 86 & 36 \\
\hline 2 & $\begin{array}{l}\text { M. Ehsaei } \\
\text { et al. (8) }\end{array}$ & 85 & 64 & 45 & 30 \\
\hline 3 & $\begin{array}{l}\text { Elbashir } \\
\text { G Ahmed } \\
\text { et al. (15) }\end{array}$ & 66 & 72 & 70 & - \\
\hline 4 & Fam et al. & 100 & - & - & \\
\hline
\end{tabular}




\begin{tabular}{|r|l|c|c|c|c|}
\hline S.N. & Study & $\begin{array}{c}\text { Back } \\
\text { pain }\end{array}$ & $\begin{array}{c}\text { Parapares } \\
\text { is }\end{array}$ & $\begin{array}{c}\text { sensory } \\
\text { loss }\end{array}$ & $\begin{array}{c}\text { Autonomic } \\
\text { disturbance } \\
\text { s }\end{array}$ \\
\hline 5 & $\begin{array}{l}\text { Pertuiset } \\
\text { et al. (17) }\end{array}$ & 97 & - & - & - \\
\hline 6 & $\begin{array}{l}\text { Leibert et } \\
\text { al. (18) }\end{array}$ & 100 & - & - & - \\
\hline 7 & $\begin{array}{l}\text { Puigdeng } \\
\text { olas et al. } \\
(19)\end{array}$ & 100 & - & - & \\
\hline
\end{tabular}

Table 8

Type of operation performed

\begin{tabular}{|l|r|r|}
\hline operative procedure & $\begin{array}{l}\text { Number of } \\
\text { patients }\end{array}$ & Percentage \\
\hline $\begin{array}{l}\text { Decompression alone } \\
\text { Decompression with } \\
\text { instrumentation }\end{array}$ & 25 & 50 \\
\hline
\end{tabular}

Table 9

Comparison of effectiveness between both procedure after 6 month

\begin{tabular}{|c|c|c|c|}
\hline $\begin{array}{l}\text { Sign \& } \\
\text { Symtoms }\end{array}$ & $\begin{array}{l}\text { Patients got } \\
\text { relieved by } \\
\text { Decompression } \\
\text { alone \% }\end{array}$ & $\begin{array}{l}\text { Patients got } \\
\text { relieved by } \\
\text { Decompression } \\
\text { with } \\
\text { instrumentation } \\
\%\end{array}$ & $\begin{array}{l}\text { P- } \\
\text { Value }\end{array}$ \\
\hline Pain relief & 96 & 80 & 0.831 \\
\hline $\begin{array}{l}\text { improvement in } \\
\text { power }\end{array}$ & 77 & 78 & 0.977 \\
\hline $\begin{array}{l}\text { improvement in } \\
\text { sensation }\end{array}$ & 71.5 & 91 & 0.598 \\
\hline $\begin{array}{l}\text { improvement in } \\
\text { Autonomic } \\
\text { system }\end{array}$ & 25 & 50 & 0.466 \\
\hline Mobility & 77 & 91 & 0.716 \\
\hline $\begin{array}{l}\text { improvement in } \\
\text { Cobb's angle }\end{array}$ & 28 & 84 & 0.0312 \\
\hline
\end{tabular}

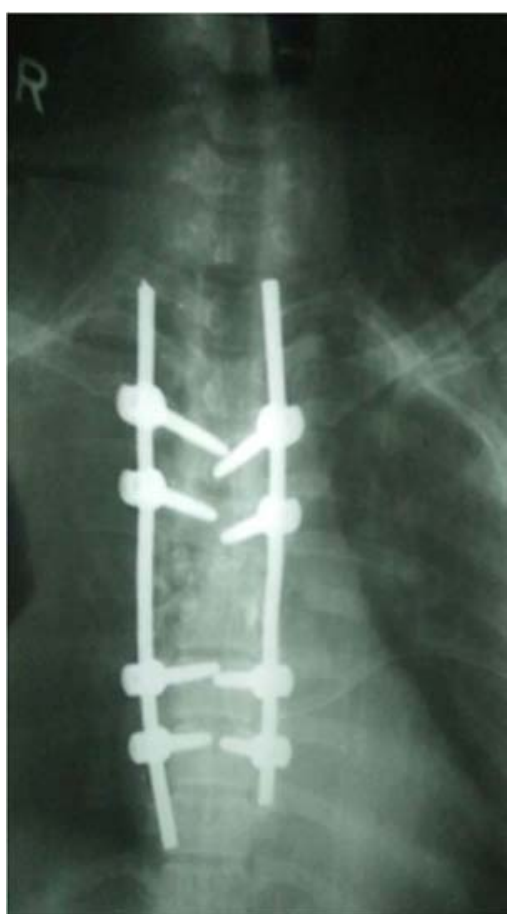

Post op xray of patient operated for D4-5 Pott's spine by Decompression with instrumentation
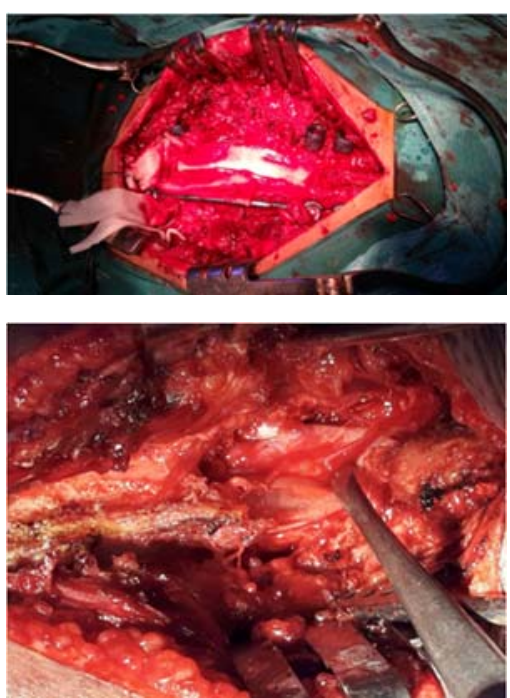

Intra Op images showing decompression with instrumentation and decompression alone. 


\section{Following conclusions were derived from the study:}

- The incidence of disease was equal in both males and females.

- Mean age was 38.24 years and ranging from 4 years to 68 years.

- Dorsal spine was most commonly involved and in dorsal spine lower dorsal spine is involved most commonly.

- Backache was the most common presenting symptom (100\%) and patient came to the hospital with motor weakness in $90 \%$ cases.

- All the cases were proven histologically to be tubercular in origin.

- No death was recorded in the present study.

- Decompression with instrumentation group is the surgical procedure of choice for thoracolumbar Pott's spine as this is simple, safe procedure with improved stability of spine and improved and early mobility on long term follow up.

\section{Correspondence:}

Dr. Asheesh Kumar Gupta M.Ch. resident Department of Neurosurgery G.R. Medical College Gwalior, India

Address- Room no. 39 Senior Boys Hostel

G.R. Medical College Gwalior

Mobile No.- 7828832632

Email-asheesh_gsvm@yahoo.com

\section{References}

1. Taylor GM, Murphy E, Hopkins R, Rutland P, Chistov Y. First report of Mycobacterium bovis DNA in human remains from the Iron Age. Microbiology 2007; 153:1243-1249.

2. LifesoRM,WeaverP,HarderEH.Tuberculous spondylitis in adults .AmJ Bone Joint Surg 1985; 67:1405-141.

3. Gorse GJ, Pais MJ, Kusske JA, Cesario TC. Tuberculous spondylitis: a report of six cases and review of the literature. Medicine (Baltimore) 1983; 62:178-193. 4. Five-year assessments of controlled trials of ambulatory treatment, debridement and anterior spinal fusion in the management of tuberculosis of the spine. Studies in Bulawayo (Rhodesia) and in Hong Kong. Sixth report of the Medical Research Council Working Party on Tuberculosis of the Spine. J Bone Joint Surg Br 1978; 60:163-177.

5. A 10-year assessment of a controlled trial comparing debridement and anterior spinal fusion in the management of tuberculosis of the spine in patients on standard chemotherapy in Hong Kong. Eighth Report of the Medical Research Council Working Party on Tuberculosis of the Spine. J Bone Joint Surg Br 1982; 64:393-398.

6. A 10-year assessment of controlled trials of inpatient and outpatient treatment of plaster-of-Paris jackets for tuberculosis of the spine in children on standard chemotherapy. Studies in Masan and Pusan, Korea. Ninth report of the Medical Research Council Working Party on Tuberculosis of the Spine. J Bone Joint Surg Br 1985; 67:103-110.

7. Jain AK, Kumar S, Tuli SM. Tuberculosis of spine [C1-D4]. Spinal Cord 1999; 37:362-369.

8. M. Ehasei et al (Medical Journal of the Islamic Republic of Iran.Vol. 23, No. 4, February, 2010. pp. 200206).

9. Park DW. Outcome and management of spinal tuberculosis according to the severity of disease: a retrospective study of 137 adult patients at Korean teaching hospitals. Spine (Phila Pa 1976) 2007;32:E130E135. 
10. Kenyon PC, Chapman AL. Tuberculous vertebral osteomyelitis: findings of a 10-year review of experience in a UK centre. J Infect. 2009;59:372-373.

11. Su SH, Tsai WC, Lin CY, Lin WR, Chen TC, Lu PL, et al. Clinical features and outcomes of spinal tuberculosis in southern Taiwan. J Microbiol Immunol Infect. 2010;43:291-300.

12. Barriere V, Gepner P, Bricaire F, Bletry O, Caumes E. Current aspects of spinal tuberculosis: apropos of 16 case reports. Ann Med Interne (Paris) 1999;150:363-369.

13. Alothman A, Memish ZA, Awada A, Al-Mahmood S, Al-Sadoon S, Rahman MM, et al. Tuberculous spondylitis: analysis of 69 cases from Saudi Arabia. Spine (Phila Pa 1976) 2001;26:E565-E570.

14. Solagberu BA, Ayorinde RO. Tuberculosis of the spine in Ilorin, Nigeria. East Afr Med J. 2001;78:197199.

15. Ahmed EG, Elbadawi NEE, Ibrahim EK, Mohammed MM (2013) Clinical Presentation of Pott's disease of the
Spine in Adult Sudanese Patients. J Med Microb Diagn 2: 120 .

16. Fam AG, Rubenstein J. Another look at spinal tuberculosis. J Rheumatol. 1993;20:1731-1740.

17. Pertuiset E, Beaudreuil J, Lioté F, Horusitzky A, Kemiche F, Richette P, et al. Spinal tuberculosis in adults. A study of 103 cases in a developed country, 1980-1994. Med (Balt) 1999;78:309-320.

18. Leibert E, Schluger NW, Bonk S, Rom WN. Spinal tuberculosis in patients with human immunodeficiency virus infection: clinical presentation, therapy and outcome. Tuber Lung Dis. 1996;77:329-334.

19. Puigdengolas X, Iranzo D, Pol M, Perez R, Ubierna MT, Olive A, et al. Tuberculous spondylodiscitis. Retrospective study of 14 cases. Rev Esp Reumatol. 1993;20:151-154. 